\title{
УСПЕШАН ЗДРАВСТВЕНИ МЕНАЏЕР
}

Весна Томић ${ }^{1}$

\section{SUCCESSFUL MEDICAL MANAGER}

Vesna Tomić

\section{Сажетак}

За спровођене руковођења у здравственим установама кључну улогу имају руководиоци. Они су посебно одговорни за стварање ресурса и юихово коришћење.

Здравственименачер треба да имапоред професионалних знања и знања из области планирана, организачије, примениваьа, контролисања, одлучивања о здравственој служби.

Здравствени менаиер треба да води рачуна о људима, ресурсима и ијиљевима.

Ефикасан здравствени меначер треба да је ефикасан за све нивое здравствене заштите, за здравствену организаиију, за људе у заједниии, за себе самог.

Кључне речи: Људски ресурси, ауторитет, одговорност, самопрочена ефикасности, стилови руковођења.

\section{Summary}

For realization of health system management key role have managers.

Manager of the health organization should have professional knowledge, knowledge of planning, organisation, application, controlling and making decision about health services.

Health manager has to take care about people, resources and aims of the health system. Efficiency of health manager should be efficient for all people in the health system, for all health organizations, and for himself.

Key words: Health resources, authority, self estimate, responsibility, successfully manager.

\section{УВОД}

3 дравствени систем, као сложен подсистем друштва повезан је са другим подсистемима: науком, образовањем, економијом. Да би успешно функционисао, сви делови треба да су функционално повезани, а у пракси се то остварује успешним управљањем.

За реализацију су потребни предуслови:

1. Општи (политика, култура, економски систем);

2. Специфични (индивидуални - успешни менаџер).
Успешни менаџери свих нивоа који знају да планирају, организују, контролишу, комуницирају своје активности и делатност установе умногоме доприносе не само ефикасности здравствене организације него и функционисању здравственог система и квалитету здравствене заштите.

Циљ рада је да проблематизира и размотри неке домене деловања успешног менаџера у управљању људским ресурсима у здравственом систему.

Рад је инспирисан чињеницом да поред знања и вештина (техничких, концептуалних, интерперсоналних) постоји широко

' Др мед. Весна Томић, социјални психолог, научни сарадник, Институт за јавно здравље Србије „Др Милан Јовановић-Батут“, Београд. 
поље данас неопходних вештина из домена психологије интерперсоналних односа недовољно упражњаваних у нашој средини, што директно утиче и на сатисфакцију запослених здравствених радника и на задовољство корисника здравственим услугама.

\section{УЛОГЕ И ПОСЛОВИ УСПЕШНОГ МЕНАЦЕРА}

Менаџери обављају основне функције играјући различите улоге под којима се подразумева одређени сет понашања. Минзберг (Mintzberg, 1973) разврстава менаџерске улоге у следеће категорије:

1. Интерперсоналне улоге,

2. Информационе улоге,

3. Улоге одлучивања.

Ад. 1.

a) Челна фигура - испољава се у церемонијалним, свечаним функцијама;

б) Лидер - подстицање запослених, селекција, обучавање, промовисање, именовање;

в) Везиста - стална комуникација са осталим члановима менаџерске мреже.

Ад. 2.

a) Монитор - претраживање, примање и селекција информација;

б) Расејивач - дисперзија, преношење информација;

в) Спикер - преношење информација у јавности.

Ад. 3.

a) Организатор - организација нових послова;

б) Водитељ у кризним ситуацијама ангажовање по потреби у времену кризе;

в) Распоређивач ресурса - планирање и распоређивање кадрова и опреме;

г) Преговарач - усклађивање различитих мишљења, решавање конфликата.

Када се анализирају послови менаџера, постоје значајне разлике у процентима распоређеног времена за одређене послове прве и средње линије, али им је садржај заједнички. Садржај послова подразумева контролисање, решавање техничких проблема, планирање радних активности, комуникацију, подучавање сарадника.

Највећи део времена менаџер проводи у комуникацији са надређенима и подређенима, као и у планирању, организацији и вођењу послова.

Пословно управљање здравственим системом директно утиче на квалитет здравствене заштите, задовољство корисника квалитетом здравствених услуга, као и на здравствено стање становништва. Све наведено, у неадекватним социјално-економским условима наше средине, транзицији као трајном стању, губитку ауторитета здравствене професије, поремећеном квалитету интерперсоналних односа на релацији здравствени радник - корисник, услуге указују на редовно мултиплицирање проблема у функционисању здравственим системом.

Шта може да учини успешан здравствени руководилац у сложеној социјално-економској ситуацији? Сигурно може да се професионално (компетентно) и морално (одговорно) бави својим послом, као и да континуирано унапређује комуникацију са пацијентом. Све то иако делује да је мало, у пракси је јако много.

\section{КАРАКТЕРИСТИКЕ УСПЕШНОГ МЕНАЦЕРА}

Коришћење дефиниције здравственог менаџера описује га као здравственог стручњака који обавља руководеће функције и задатке, одговоран је за стварање ресурса и њихово коришћење, све у циљу остваривања постављених циљева здравствене организације.

Из наведене дефиниције може да се закључи да је успешан менаџер онај ко: 
- обавља све функције и задатке,

- ствара ресурсе финансијске, кадровске, и неопходна знања,

- рационално користи ресурсе,

- постиже постављене циљеве,

- успешно комуницира са људима.

У интересу је сваке организације и институције, посебноздравствене, гдерадељуди са људима и за људе, императив је код одабира руководећег кадра њихово психолошко тестирање одговарајућим батеријама мерних инструмената у циљу побољшања радне ефикасности свих запослених, као и превенције лоших међуљудских односа, психолошког малтретирања и неадекватне радне мотивације.

Активности које су у опису посла здравствених менаџера су:

1. Планирање рада институције;

2. Организација радних активности и задатака;

3. Реализација планираних активности;

4. Контрола реализације послова;

5. Координација рада запослених, ефикасна комуникација и решавање потенцијалних и латентних конфликата;

6. Мотивисање запослених;

7. Стварање интелектуално подстицајне радне средине и позитивне психолошке климе;

8. Колаборација са другим организацијама;

9. Делегирање адекватних стручних ауторитета;

10. Одлучивање на основу анализе ситуације.

Успешан менаџер потребан је свим нивоима хијерархије од тимског управљања до топ менаџера. Уколико на неким нивоима нема успешних руководилаца, то ће у већој или мањој мери да утиче на управљање целим системом.

\section{ПРОЦЕНА УСПЕШНОСТИ РАДА МЕНАЦЕРА}

Процена успешности рада менаџера најчешће се врши према резултатима које здравствена установа остварује као објективне показатеље, али нису мање важни и субјективни показатељи ефикасности, међу којима се истичу психолошка клима организације, мотивација запослених за квалитет радне активности и сатисфакција запослених.

Један од проблема честих у пракси јесте психолошко малтретирање запослених од стране руководилаца. Прва превентивна мера за решавање овог проблема је психолошко тестирање менаџера ради провере њиховог менталног статуса и вештина и знања у управљању људским ресурсима.

Велики број руководилаца под паролом обима посла запоставља рад са запосленима у циљу подизања квалитета интерперсоналних односа и унапређивања квалитета рада. Обично се тога сете када дође до проблемских, конфликтних ситуација које не умеју ефикасно да реше.

При процени рада менаџера обично се полази од функција које он обавља:

- планирања,

- организације,

- контроле,

- комуникације.

Ове параметре пожељно је допунити проценом: како менаџер решава проблеме, како одлучује, да ли прати промене у окружењу, да ли има увид у своје предности и недостатке, како користи доступне ресурсе.

Оцену рада руководилаца треба да обављају независнатела изван институције у оном делу који мере објективне показатеље, као и да пишу писмене извештаје о томе. Интерна процена запослених о квалитету интерперсоналних односа, радној мотивацији и начину комуникације руководилаца обављају професионалци запослени у институцији - психолози због коришћења мерних инструмената и интерпретације резултата. 


\section{САМОПРОЦЕНА УСПЕШНОСТИ РАДА}

Тренд у развијеним земљама јесте самопроцена менаџера. Узимајући у обзир кључни недостатак ове методе, необјективност особе, сматрамо да је оно далеко од пожељне примене у нашој пракси. У времену минимизирања професионалне одговорности, овај проблем наводимо само као светски тренд.

Као такав може да нађе своје место као допуна објективне процене независног процењивача у форми одговора на питање: „Како да будем бољи менаџер?!“

И поред свих досадашњих покушаја процена и самопроцена идентификовања успешног и неуспешног руководиоца то није једноставан посао. Постоји велики број метода, инструмената и покушаја у том правцу. И на крају и кључно питање - кога тај проблем интересује у нашим условима?!

Из резултата истраживања наводимо да успешан менаџер треба да:

1. Учествује у свим активностима организације.

2. Издваја људе који добро раде и јавно их похваљује.

3. Према потреби помаже људима у организацији, испољава хуманост.

4. Испољава поштовање и негује професионално достојанство.

5. Реално процењује ситуације и могућности које организација омогућује.

Ефикасност менаџера је важна за функционисање менаџера, а ефективност је кључ успеха организације.

Ефикасан је онај менаџер који у оквиру свог стварног ауторитета и одговорности чини ствари на прави начин.

Ефективан менаџер је онај који у оквиру свог ауторитета и одговорности чини праве ствари.

Ефективан менаџер зна да препозна личне јаке и слабе стране и да прихвати да се основне вештине могу побољшати.

\section{САВЕТИ ЗА ЗДРАВСТВЕНЕ МЕНАЦЕРЕ}

1. Напишите који су ваши циљеви.

2. Хвалите своје сараднике јавно.

3. Иновирајте садржаје рада.

4. Усмерите обуку на специфичне вештине.

5. Гледајте на сараднике као на вредност.

6. Критикујте грешке, са објашњењем.

7. Дефинишите рокове за постављене циљеве.

8. У комуникацији тражите сва мишљења, не само истомишљенике.

9. Управљајте као да немате овлашћења.

10. Радите и комуницирајте транспарентно.

11. Изграђујте тимски рад.

12. Обезбедите интегрисање индивидуалних напора.

13. Посматрајте људе као појединце, не као особље.

14. Цените самосталност и кохерентност тимова.

15. Признајте грешку ако сте је учинили.

16. Управљајте сопственим примером.

17. Ојачајте кооперативну, а не компетитивну психолошку климу.

18. Истичите стално побољшавање.

19. Негујте заједничке вредности.

20. Шаљите повратне информације сарадницима.

21. Користите уједначено људске ресурсе.

22.Планирајтесопственипрофесионални развој и развој својих сарадника.

\section{СТИЛОВИ МЕНАЦЕРА У КОНФЛИКТНИМ СИТУАЦИЈАМА}

Конфликата увек има у радним организацијама и они не карактеришу лоше руководиоце. Могу се дефинисати као вид супротстављања две стране, а психолошку основу им чини инкомпатибилност циљева и/или вредности. 
Интерперсонални конфликти менаџера се могу одредити као:

- неусаглашеност интереса око циљева, политике или средстава за достизање циљева у организацији;

- неусаглашеност облика понашања или емотивна реаговања обојена стереотипом, страхом, бесом или одбацивањем запослених.

C обзиром на то да су неизбежни на радном месту, руководилац треба да је обучен за њихово решавање и управљање њима као један од важних задатака. Сагледамо ли тај проблем са социјално-психолошких позиција, намеће се неопходним оспособљавање за њихово решавање као један од приоритета да не би ескалирали или остали латентни или резутирали хроничним незадовољством запослених.

Карактеристике конфликата у здравственим организацијама су:

1. Недостатак привржености општим вишим циљевима.

2. Неадекватна оптимизација многоструких циљева - може се остварити путем координације, интеграције, поверења, колаборације чланова унутар групе.

3. Двосмисленост основних циљева.

4. Обим посла - различита намерна лоша и неадекватна подела посла.

5. Природа посла.

6. Недостатак толеранције.

7. Уговорни односи.

8. Прекомерна специјализација и многоструки ауторитет.

9. Структура моћи.

Различита су гледања на конфликтне ситуације на радном месту, али без обзира на то како успешно да се разреше, оне остављају трајан траг у структури и динамици интерперсоналних односа, трајно утичу на квалитет психолошке климе на послу и смањују радну ефикасност, те стога у сваком случају имају лош утицај на запослене. Неки аутори их сматрају подстица- јним и развојним за посао, али боље их је избегавати него сматрати корисним.

\section{ПОНАШАЫА МЕНАЦЕРА У КОНФЛИКТНИМ СИТУАЦИЈАМА}

Каква су могућа понашања менаџера у конфликтним ситуацијама размотрићемо у наставку текста. Амерички психолог Dunett („Организација и индивидуална психологија“) издваја следеће стилове понашања:

1. Избегавање конфликата

Менаџер који преферира овакав облик понашања настоји да се склони пред конфликтом или да га емотивно контролише. Овај облик понашања често води у кумулирање неразрешених конфликата са лошим последицама на интерперсоналне односе и радну ефикасност.

2. Изглађивање конфликата

Карактерише га минмизирање или потискивање реалних извора конфликата у радној средини. Овакво понашање ослања се на кооперацију и редукцију тензија.

\section{3. Форсирање}

Подразумева да менаџер користи методе присиле и доминације, занемарујући интересе друге стране. Своје оштре поступке правда интересима фирме.

\section{4. Компромис}

Циљ је постизање сагласности страна у сукобу у коме обе стране делимично одустају од почетних захтева.

\section{5. Сарадња}

Понашање менаџера у коме доминира сарадња са циљем да се задовоље све стране у сукобу.

Начин који менаџер бира у циљу разрешавања конфликтне ситуације зависи од структуре његове личности, искуства, способности, услова у којима живи и ради.

Много је проблема, тешких ситуација и одлука које менаџер мора да решава уколико жели да обавља сложене послове, што указује на бројне и по природи хетерогене изворе стреса у његовом руковођењу. 


\section{ИНСТРУМЕНТИ ЕФЕКТИВНОСТИ МЕНАЦЕРА}

Да би се повећала ефективност менаџера поред одређеног знања и интерперсоналних вештина, потребно је оспособити их за коришћење неких инструмената, као што су: коришћење анализе, идентификација проблема, анализа ограничења, методологија истраживања, процес доношења одлука, решавање конфликата.

Сваки од наведених инструмената захтева развој неких персоналних диспозиција и психолошких варијабли личности, као и увид у бављење квалитетом интерперсоналних односа.

\section{УСПЕШАН МЕНАЦЕР И УПРАВЉАЫЕ ЉУДСКИМ РЕСУРСИМА}

Знати радити са људима једна је од важних карактеристика руководиоца. Досадашња истраживања су показала да та варијабла чини пола успеха и обрнуто, па се зато пуна пажња поклања образовању менаџера у области развоја социјалних вештина, као и социјалне и емоционалне интелигенције.

Развој ауторитета, селекција кадрова и развој професионалне каријере су садржаји о којима се доста говори и у свету интензивно ради.

Под ауторитетом се подразумева улога која се даје једној особи да би организовала посао са људима којима руководи и које контролише.

Ауторитет подразумева и способност људи да приме моћ проистеклу из њихових способности и релевантних знања и звања. У изградњи ауторитета особе, поред положаја и улоге које су му привремено дате, учествује целокупна његова личност и понашање. Уколико особа нема ауторитет, тешко да организациона јединица може да буде ефикасна.

Ауторитет може да буде формалан и неформалан.
Неформалан ауторитет се ствара на основу искуства, понашања, знања, професионалног угледа и професионалне одговорности. Основа му је професионално покриће и у складу са тим одговарајућа социјална перцепција сарадника.

Формални ауторитет подразумева моћ на основу закона и прописа да се пренесе утицај. Основа му је положај који менаџер заузима према социјалној хијерархији организације.

Пракса показује да непоштовања формалног ауторитета од стране сарадника има, посебно у случајевима када је менаџер нижег степена професионалног звања и знања од сарадника у њему.

Неки од предуслова за прихватање формалног ауторитета су да изабрани руководилац буде:

- професионално компетентан и у струци

и у управљању људским ресурсима;

- са највишим степеном стручне спреме и звања, као и јавним професионалним референцама;

- са моралним кредибилитетом;

- одговарајући тип личности за рад са људима.

Један од начина расподеле званичног ауторитета јесте делегирање дуж организационе структуре. Може да буде са вишег на ниже нивое менаџмента или са менаџера на запослене. С обзиром на то да подразумева и преношење одговорности, добро је мотивационо средство и један од начина за побољшање ефикасности.

Успешан менаџер креира и одржава свеукупне услове у којима људи раде да би испунили циљеве организације. Запослени имају своје циљеве и потребе који су за њих лично веома важни: да буду адекватно награђени, да се осећају сигурним, безбедне услове на раду. И шире - да кроз осећај опште животне сигурности могу да задовоље своје социјалне потребе кроз дружење и уважавање, да буду похваљени за допринос који остварују, да напредују и да 
се њима поштено и компетентно руководи, потреба да организација у којој ради има перспективу и углед.

Обављајући своје функције, менаџер помаже људима да задовоље и остваре своје потенцијале, испоље способност и креативност, допринесу напредовању организације и да буду професионално и персонално задовољни и мотивисани за рад.

Учинак људи на раду остварује се у функцији две групе фактора:

- Способности, вештине, знања и искуства;

- Мотивацији да се фактори из наведене групе испоље у добрим околностима на послу.

Мотивација људи на раду биће ефикасна ако они удружују свој потенцијал са циљевима организације и притом остварују личне и професионалне циљеве.

\section{ПЛАНИРАЫЕ ПРОФЕСИОНАЛНОГ РАЗВОJA}

Развој здравственог менаџмента захтева израду плана за развој каријере за све који имају способности за руковођење. Сваки руководилац поред професионалних знања, мора да зна да ради са људима и да побољшава кадровску структуру организације чиме ће побољшати њену ефикасност.

Професионални развој кадрова захтева планирање деловања на основу њиховог знања, остварених вештина и мотивација за усавршавање.

Сваки руководилац треба да буде „учитељ“ - едукатор.

Успешан менаџер треба да зна:

- да изради план и програм усвршавања;

- организује едукацију;

- мотивише људе за усавршавање;

- да пренесе важне поруке;

- да одговорно анализира, закључује, коментарише;

- да евалуира усавршавање.
Када се ради о личном усавршавању, менаџер треба да:

1. Саслуша ставове, мишљења, примедбе колега.

2. Компарира своје знање и вештине са другима.

3. Објективно оцени свој допринос развоју делатности установе.

4. Идентификује своје позитивне и негативне стране рада.

Руководилац мора да зна, АЛИ И ДА ПРИМЕЊУЈЕ, СТЕЧЕНА ЗНАЮА ИЗ области управљања људским ресурсима, о чему је здравственим кадровима потребно допунско образовање.

\section{ЗАКЈЉУЧАК}

Руковођење здравственим системом треба да избалансира потребе свих учесника у здравственој заштити: чланова заједнице, корисника здравствене заштите, даваоца здравствених услуга, организације у којима људи раде и средине у којој људи живе.

Ако је општи циљ здравственог система здравље народа, онда је здравствени менаџмент „организован и развијен систем правила, функција и задатака које спроводе одговорни појединци на различитим нивоима здравствене заштите“.

Немогућ је развој здравственог менаџмента без интердисциплинарног приступа његовој теорији и пракси, посебно апликације социјалних и индивидуалних психолошких знања и вештина у медицинској пракси. У центру образовања из бихевиоралне медицине јесте човек.

Одговорност и степен ауторитета здравственог руководиоца зависе од тога како руководи послом (резултатима које остварује) и људима.

Штојешири нивоактивностиздравствене службе, то су сложеније менаџерске обавезе и проблеми које треба да реши.

Посебна пажња обраћа се на: 
- знања која руководилац треба да има (чињенице, принципе, стратегије);

- практичне вештине и способности у социјалним интеракцијама (техничке, интерперсоналне, хумане);

- како да унапреди своје ставове и понашање (мотивација, комуникација, стрес).

\section{ПОРУКА}

СЗО наводи да су вештине доброг здравственог менаџера:

1. Пружање одговарајућих здравствених услуга свим људима.
2. Одлучивање о технологији коју ће да примени.

3. Комуникација ради унапређивања здравог начина живота.

4. Вођење заједнице и уливање поверења људима из ближег и даљег социјалног окружења.

5. Руковођење, хармонично функционисање са појединцима и организацијама унутар и ван система здравствене заштите.

\section{ЛИТЕРАТУРА}

1. Чизмић С, Бојановић Р и сарадници, Психологија и менаимент, Филозофски факултет, Институт за психологију, Београд, 1995.
2. Мићовић П, Менаимент здравственим системом, ECPD, Београд, 2000.

3. Томић В, Особине личности менаиера, Здравствена заштита, 2004; 3: 24-30.

Контакт: Др мед. Весна Томић, социјални психолог, научни сарадник, Институт за јавно здравље Србије „Др Милан Јовановић-Батут“, Београд 